\title{
Article \\ The Chemical Element Composition of Turmeric Grown in Soil-Climate Conditions of Tashkent Region, Uzbekistan
}

\author{
Dilfuza Jabborova $^{1,2}{ }^{\mathbb{D}}$, Ravish Choudhary ${ }^{3} \mathbb{D}$, Rohini Karunakaran ${ }^{4, *}{ }^{\mathbb{D}}$, Sezai Ercisli ${ }^{5}\left(\mathbb{D}\right.$, Jyoti Ahlawat ${ }^{6}$, \\ Khurshid Sulaymanov ${ }^{1}$, Abdulahat Azimov ${ }^{1}$ and Zafarjon Jabbarov ${ }^{7}$
}

1 Laboratory of Medicinal Plants Genetics and Biotechnology, Institute of Genetics and Plant Experimental Biology, Uzbekistan Academy of Sciences, Tashkent Region, Kibray 111208, Uzbekistan; dilfuzajabborova@yahoo.com (D.J.); ksulaymanov@yahoo.com (K.S.); ahat2021@yahoo.com (A.A.)

2 Division of Microbiology, ICAR-Indian Agricultural Research Institute, Pusa, New Delhi 110012, India

3 Division of Seed Science and Technology, ICAR-Indian Agricultural Research Institute, New Delhi 110012, India; ravianu1110@gmail.com

4 Unit of Biochemistry, Faculty of Medicine, AIMST University, Semeling, Bedong 8100, Malaysia

5 Department of Horticulture, Agricultural Faculty, Ataturk University, Erzurum 252240, Turkey; sercisli@gmail.com

6 Department of Biotechnology, GD Goenka University, Gurugram, Haryana 122102, India; j.10dec@gmail.com

7 Faculty of Biology, National University of Uzbekistan, Tashkent 100174, Uzbekistan; zafarjonjabbarov@gmail.com

* Correspondence: rohini@aimst.edu.my

Citation: Jabborova, D.; Choudhary, R.; Karunakaran, R.; Ercisli, S.; Ahlawat, J.; Sulaymanov, K.; Azimov, A.; Jabbarov, Z. The Chemical Element Composition of Turmeric Grown in Soil-Climate Conditions of Tashkent Region, Uzbekistan. Plants 2021, 10, 1426. https://doi.org/ 10.3390/plants10071426

Academic Editors: Ismael Aranda, Fernando Henrique Reboredo and Roberta Masin

Received: 13 May 2021

Accepted: 5 July 2021

Published: 12 July 2021

Publisher's Note: MDPI stays neutral with regard to jurisdictional claims in published maps and institutional affiliations.

Copyright: (c) 2021 by the authors. Licensee MDPI, Basel, Switzerland. This article is an open access article distributed under the terms and conditions of the Creative Commons Attribution (CC BY) license (https:// creativecommons.org/licenses/by/ $4.0 /)$.
Abstract: A mineral fertiliser has positive effects in improving turmeric nutrients, soil enzymes and soil properties. The aim of this research was to study the effect of mineral fertilisers on the content of mineral elements in turmeric rhizome, soil enzymes activity and soil properties in the Tashkent Region, Uzbekistan. For the first time in Uzbekistan, the turmeric rhizome was cultivated to study the mineral elements present in the rhizome. A microplot experiment was conducted with four treatments including T1 (Control), T2 $\left(\mathrm{N}_{75} \mathrm{P}_{50} \mathrm{~K}_{50} \mathrm{~kg} / \mathrm{ha}\right), \mathrm{T} 3\left(\mathrm{~N}_{125} \mathrm{P}_{100} \mathrm{~K}_{100} \mathrm{~kg} / \mathrm{ha}\right)$ and $\mathrm{T} 4\left(\mathrm{~N}_{100} \mathrm{P}_{75} \mathrm{~K}_{75}+\mathrm{B}_{3} \mathrm{Zn}_{6} \mathrm{Fe}_{6} \mathrm{~kg} / \mathrm{ha}\right)$ and turmeric rhizome, which were collected for observation along with the soil samples. The analyses indicated that the NPK + BZnFe (100:75:75:3:6:6 kg/ha) treatment significantly improved minerals such as $\mathrm{K}, \mathrm{Ca}, \mathrm{P}, \mathrm{Mg}$ and $\mathrm{Na}$ contents rhizome as compared to the control without fertiliser. Likewise, the maximum quantity of micronutrient content viz., $\mathrm{Fe}, \mathrm{Mn}, \mathrm{Zn}, \mathrm{Cu}, \mathrm{Cr}$ and $\mathrm{Si}$ was also recorded in turmeric rhizome treated with NPK + BZnFe $(125: 100: 100: 3: 6: 6 \mathrm{~kg} / \mathrm{ha})$. It showed an increase in these micronutrients in the rhizome compared to the control, followed by a low rate of NPK (75:50:50 kg/ha). The highest content in terms of total $\mathrm{N}, \mathrm{P}, \mathrm{K}$ content, humus, active phosphorus, potassium, and enzymes activity was also observed in soil with the treatment of mineral fertiliser viz., NPK + BznFe (100:75:75:3:6:6 kg/ha), which enhanced soil nutrient and enzyme activity. The NPK + BznFe (100:75:75:3:6:6 kg/ha) treatment significantly increased the active $\mathrm{N}$ content by $40 \%$, total $\mathrm{P}$ content by $38 \%$ and total $\mathrm{K}$ content by $22 \%$ in comparison to the control without mineral fertiliser. Overall, it was found that NPK + BznFe (100:75:75:3:6:6 kg/ha) was significantly valuable for enhancing the total nitrogen, phosphorus, and potassium levels in the soil compared to control, which is useful for improving soil health in terms of soil enzyme and soil nutrients. Additionally, the micronutrients in turmeric rhizome were significantly enhanced when using this combination of fertiliser applications [NPK + BznFe (100:75:75:3:6:6 kg/ha)]. Therefore, this present study revealed that the NPK+BznFe (100:75:75:3:6:6 $\mathrm{kg} / \mathrm{ha}$ ) could produce the most significant yield of high-quality turmeric plants and improve soil properties in Uzbek soil-climate conditions.

Keywords: turmeric; macroelements; microelements; mineral fertilisers; soil nutrients; soil enzymes 


\section{Introduction}

Herbal plants are an important source of traditional medicine and play a key role in global health [1-5]. Turmeric (Curcuma longa L.) belongs to the family Zingiberaceae, which includes rhizomatous herbaceous perennial herbs with heights of 60 to $90 \mathrm{~cm}$; there are more than 40 commercially cultivated species of Curcuma longa [6]. It is a tropical South Asian native crop which is widely cultivated in the tropical and subtropical regions of the world. The yellow-coloured turmeric powder, mainly used as spices or traditional Ayurvedic medicine in India, is comprised of half-boiled and dried rhizomes. It is extensively used as a stimulant, carminative, aspirant, cordial, astringent, diuretic, martinet and anti-inflammatory, anticancer, chronic anterior uveitis and pancreatitis, cardioprotective [7,8], hypoglycaemic [9], antiamyloidogenic [10], antifungal [11], parasitical [12] and antioxidant treatment $[13,14]$. Its aroma and colour come from the essential oils and curcumin present in turmeric [15]. Additionally, curcumin plays a vital role in inducing apoptosis and antiangiogenic activity [16,17].

As Curcuma contains curcumin, which makes it a natural food additive and food colourant, and has medicinal properties, such as anti-cancer and antiviral properties, global demand for it is likely to increase, especially in Western countries. Curcumin has a long scientific history dating back to ancient times and has attracted modern research interest for the past four decades. It is rich in several essential minerals such as $\mathrm{Fe}, \mathrm{Ca}, \mathrm{Mg}$, and $\mathrm{P}$ and vitamin A and widely used in drinks and supplements [18].

The fertility of soil is maintained by adding extra fertilisers and different kinds of manure and macronutrients from chemical fertilisers [19]. Soil property and crop yield can be improved using main elements such as $\mathrm{N}, \mathrm{P}$, and $\mathrm{K}$ and secondary nutrients such as $\mathrm{Mg}$ in either organic or inorganic form. Mg plays an essential role in many biochemical and physiological processes in plants [20]. Foliar spray with a higher concentration of $\mathrm{MgSO}_{4}$ increases yields of turmeric rhizome [21]. The combination of different fertilisers influences soil fertility, the soil's chemical properties, and crop yield and quality. Mineral fertiliser, soil $\mathrm{pH}$ and physiological properties were the most necessary for the higher mineral content of turmeric. Earlier, it was found that the local climatic and edaphic factors are essential to realising a high yield and high quality in turmeric cultivation [22,23]. Hossain and Yukio [24] also reported that grey soil containing large amounts of $\mathrm{K}$ and $\mathrm{Ca}$ led to the highest amount of $\mathrm{K}, \mathrm{Ca}$ and $\mathrm{Mg}$ contents in turmeric rhizomes.

In the Tashkent region of Uzbekistan, the soil is impoverished in terms of nutrients and minerals as turmeric is a long-duration crop and needs a high amount of additional nutrients and minerals in the soil for higher yield. Naturally, there are not enough nutrients in the soil of the Tashkent region for good quality turmeric production, as the soil of the experimental site was deficient in essential nutrients, resulting in a decrease in turmeric growth and yield. Therefore, keeping these views in mind, the present study has been undertaken to determine mineral fertilisers' effects on the analysis of the mineral nutrients in turmeric rhizome and soil enzyme properties.

\section{Results and Discussion}

\subsection{Impact of Mineral Fertilisers on Turmeric Rhizome Nutrients}

The results showed that the application of mineral fertiliser treatments such as NPK (125:100:100 kg/ha) and NPK + BZnFe (100:75:75:3:6:6 kg/ha) increased the macroelement content in the turmeric rhizome (Table 1). The NPK (125:100:100 kg/ha) significantly increased rhizome K, Ca P and $\mathrm{Mg}$ content compared to control without fertiliser. Similarly, the NPK + BZnFe (100:75:75:3:6:6 kg/ha) treatment with the highest amount of fertiliser was also significantly increased macroelement content compared to control. However, NPK + BZnFe (125:100:100:3:6:6 kg/ha) treatment showed a significant enhancement in rhizome K, $\mathrm{Ca}, \mathrm{P}, \mathrm{Mg}$ and Na contents over the control (Table 1). Several researchers have been reported the macro-micro elements in different plants [25-27]. Mineral nutrients such as N, P, K play an essential role in plant growth, development, yield and productivity $[27,28]$. According to Adekiya et al. [18], it was suggested that rhizome growth and yield were increased 
with the supply of high concentrations of nutrients and low C:N ratio, which resulted in an increase in decomposition with the nutrient release. A similar study was reported by Thenacho et al. [29] in their study on turmeric, as the deficiency of essential nutrients in the soil of the experimental site resulted in a lower yield and decrease in turmeric growth [30]. The nitrogen content of NPK formed proteins and chlorophyll content in plants which induced leaf growth. At the same time, phosphorus is necessary for root development, cell division, multiplication, and energy reactions, and potash worked for stem development, cell division, carbohydrates formation and translocation in plants, especially turmeric; it is useful for rhizome development [31]. It was reported that other macroelements such as $\mathrm{Mg}$, used for nitrogen uptake enhancement in plants, as the application of $\mathrm{Mg}$ increased the root growth by translocation and absorbed the other macronutrients in the soil, increasing rhizome growth and yield of turmeric [32]. The literature showed no studies have so far been undertaken on the determination of mineral nutrients in turmeric cultivated in Uzbekistan.

Table 1. The impact of mineral fertilisers on macroelement content of turmeric rhizome grown in soil-climate conditions of Tashkent Region.

\begin{tabular}{ccccc}
\hline \multirow{2}{*}{ Macroelements (mg/kg) } & \multicolumn{3}{c}{ Treatments } \\
\cline { 2 - 5 } & Control & $\mathbf{N}_{\mathbf{7 5}} \mathbf{P}_{\mathbf{5 0}} \mathbf{K}_{\mathbf{5 0}}$ & $\mathbf{N}_{\mathbf{1 2 5}} \mathbf{P}_{\mathbf{1 0 0}} \mathbf{K}_{\mathbf{1 0 0}}$ & $\mathbf{N}_{\mathbf{1 0 0}} \mathbf{P}_{\mathbf{7 5}} \mathbf{K}_{\mathbf{1 7 5}}+\mathbf{B}_{\mathbf{3}} \mathbf{Z n}_{\mathbf{6}} \mathbf{F e}_{\mathbf{6}}$ \\
\hline $\mathrm{K}$ & 14223.46 & 18536.65 & $24812.78^{*}$ & 20541.87 \\
$\mathrm{Ca}$ & 1958.57 & 2236.11 & 8865.55 & $13261.19^{*}$ \\
$\mathrm{P}$ & 5916.50 & 6649.30 & 7075.49 & $6795.69^{*}$ \\
$\mathrm{Mg}$ & 4544.58 & 5516.49 & 6733.86 & $7598.70 *$ \\
$\mathrm{Na}$ & 194.75 & 246.01 & 300.72 & $823.38^{*}$ \\
\hline
\end{tabular}

* All the values are the average of three replicates $(n=3)$, and the mean with the same letter (superscript) in the columns are not significantly different $(p<0.05)$-(Tukey's test).

The results on microelements found in turmeric rhizome are presented in Table 2. The microelements in turmeric rhizome were significantly increased by the NPK (125:100:100 kg/ha) and NPK + BZnFe (100:75:75:3:6:6 kg/ha) treatments (Table 2). Data regarding rhizome microelement content showed that NPK (125:100:100 kg/ha) significantly enhanced the contents of micronutrients such as $\mathrm{Fe}, \mathrm{Mn}, \mathrm{Zn}, \mathrm{Cu}, \mathrm{Cr}$ and $\mathrm{Si}$ in turmeric rhizome as compared to control. A maximum quantity of micronutrient content in turmeric rhizome was recorded with NPK + BZnFe (125:100:100:3:6:6 kg/ha), which increased Fe, Mn, Zn, $\mathrm{Cu}, \mathrm{Cr}$ and $\mathrm{Si}$ contents in rhizome over the control and low rate of NPK (75:50:50 kg/ha). Nutrient analysis by Olubunmi et al. [33] of other tuber crops such as ginger indicated their richness in calcium, magnesium, sodium, potassium, phosphorous, manganese, iron, zinc, and copper. Poultry manure alone or in combination with $\mathrm{Mg}$ fertiliser resulted in increasing other several nutrients viz., $\mathrm{Na}, \mathrm{K}, \mathrm{Mg}, \mathrm{Ca}, \mathrm{Fe}$, and vitamin contents in turmeric rhizome as compared with NPK with or without Mg fertiliser due to positive effect on soil and plants [34].

Table 2. The impact of mineral fertilisers on microelement content of turmeric rhizome grown in soil-climate conditions of Tashkent Region.

\begin{tabular}{ccccc}
\hline \multirow{2}{*}{ Microelements (mg/kg) } & \multicolumn{3}{c}{ Treatments } \\
\cline { 2 - 5 } & Control & $\mathbf{N}_{\mathbf{7 5}} \mathbf{P}_{\mathbf{5 0}} \mathbf{K}_{\mathbf{5 0}}$ & $\mathbf{N}_{\mathbf{1 2 5}} \mathbf{P}_{\mathbf{1 0 0}} \mathbf{K}_{\mathbf{1 0 0}}$ & $\mathbf{N}_{\mathbf{1 0 0}} \mathbf{P}_{\mathbf{7 5}} \mathbf{K}_{\mathbf{1 7 5}}+\mathbf{B}_{\mathbf{3}} \mathbf{Z} \mathbf{n}_{\mathbf{6}} \mathbf{F e}_{\mathbf{6}}$ \\
\hline $\mathrm{Fe}$ & 79.32 & 95.23 & 111.81 & $217.02^{*}$ \\
$\mathrm{Mn}$ & 6.67 & 7.12 & 8.37 & $11.65^{*}$ \\
$\mathrm{Zn}$ & 2.53 & 5.65 & 6.57 & $9.89^{*}$ \\
$\mathrm{Cu}$ & 1.80 & 1.92 & $1.95^{*}$ & $1.95^{*}$ \\
$\mathrm{Cr}$ & 0.95 & $1.15^{*}$ & $1.15^{*}$ & $1.15^{*}$ \\
$\mathrm{Mo}$ & 0.062 & $0.064^{*}$ & $0.064^{*}$ & $0.064^{*}$ \\
$\mathrm{Si}$ & 568.54 & 678.53 & 684.42 & $699.43^{*}$ \\
\hline
\end{tabular}

* All the values are the average of three replicates $(n=3)$, and the mean with the same letter (superscript) in the columns are not significantly different $(p<0.05)$-(Tukey's test). 
Data regarding the ultra-microelement content in turmeric rhizome showed a nonsignificant difference between all the treatments. For most ultra-micronutrients $(\mathrm{Li}, \mathrm{Be}, \mathrm{V}$, $\mathrm{Co}, \mathrm{Ni}, \mathrm{Ga}, \mathrm{Ge}, \mathrm{Nb}, \mathrm{Ag}, \mathrm{Cd}, \mathrm{Sn}, \mathrm{Sb}, \mathrm{Cs}$ and $\mathrm{W}$ content), control treatment showed higher values of rhizome nutrients than other fertiliser treatments (Table 3), while micronutrients such as In, Ta and Re were absent in turmeric rhizome in all the treatments and control. Similarly, the soil enriched with additional sulphur and magnesium resulted in the higher rhizome yields in the kacholam crop [35]. In the same way, Fe application also increased the total yield in the fenugreek crop [36]. The effects of Zn, Fe and B were also observed to be beneficial for total rhizome growth and yield in tuber crops such asginger [37] and turmeric [38].

Table 3. The impact of mineral fertilisers on ultra-microelement content of turmeric rhizome grown in soil-climate conditions of Tashkent Region.

\begin{tabular}{ccccc}
\hline \multirow{2}{*}{ Treatments } & \multicolumn{3}{c}{ Treatments } \\
\cline { 2 - 5 } & Control & $\mathbf{N}_{\mathbf{7 5}} \mathbf{P}_{\mathbf{5 0}} \mathbf{K}_{\mathbf{5 0}}$ & $\mathbf{N}_{\mathbf{1 2 5}} \mathbf{P}_{\mathbf{1 0 0}} \mathbf{K}_{\mathbf{1 0 0}}$ & $\mathbf{N}_{\mathbf{1 0 0}} \mathbf{P}_{\mathbf{7 5}} \mathbf{K}_{\mathbf{1 7 5}}+\mathbf{B}_{\mathbf{3}} \mathbf{Z n}_{\mathbf{6}} \mathbf{F e}_{\mathbf{6}}$ \\
\hline $\mathrm{Li}$ & $0.190^{*}$ & $0.190^{*}$ & $0.190^{*}$ & $0.190^{*}$ \\
$\mathrm{Be}$ & 0.008 & 0.008 & $0.009^{*}$ & $0.009^{*}$ \\
$\mathrm{~V}$ & $0.171^{*}$ & $0.171^{*}$ & $0.171^{*}$ & $0.171^{*}$ \\
$\mathrm{Co}$ & $0.048^{*}$ & 0.036 & 0.042 & 0.044 \\
$\mathrm{Ni}$ & $0.416^{*}$ & $0.416^{*}$ & $0.416^{*}$ & $0.416^{*}$ \\
$\mathrm{Ga}$ & $0.222^{*}$ & $0.222^{*}$ & $0.222^{*}$ & $0.222^{*}$ \\
$\mathrm{Ge}$ & $0.001^{*}$ & $0.001^{*}$ & $0.001^{*}$ & $0.001^{*}$ \\
$\mathrm{Nb}$ & $0.003^{*}$ & $0.003^{*}$ & $0.003^{*}$ & $0.003^{*}$ \\
$\mathrm{Ag}$ & $0.064^{*}$ & $0.064^{*}$ & $0.064^{*}$ & $0.064^{*}$ \\
$\mathrm{Cd}$ & 0.010 & 0.010 & 0.024 & $0.029^{*}$ \\
$\mathrm{In}$ & 0.000 & 0.000 & 0.000 & 0.000 \\
$\mathrm{Sn}$ & $0.0333^{*}$ & $0.0333^{*}$ & $0.0333^{*}$ & $0.0333^{*}$ \\
$\mathrm{Sb}$ & $0.007^{*}$ & 0.006 & $0.007^{*}$ & $0.007^{*}$ \\
$\mathrm{Cs}$ & $0.008^{*}$ & 0.003 & 0.006 & 0.003 \\
$\mathrm{Ta}$ & 0.000 & 0.000 & 0.000 & 0.000 \\
$\mathrm{~W}$ & 0.002 & $0.003^{*}$ & $0.003^{*}$ & 0.002 \\
$\mathrm{Re}$ & 0.000 & 0.000 & 0.000 & 0.000
\end{tabular}

* All the values are the average of three replicates $(n=3)$, and the mean with the same letter (superscript) in the columns are not significantly different $(p<0.05)$-(Tukey's test).

\subsection{Impact of Mineral Fertilisers on Soil Properties}

Results for soil mechanical composition are presented in Table 4. The data show that treatments T3 (N125P100K100 kg/ha) and T4 (N100P75K175 + B3Zn6Fe6 kg/ha) increased the mechanical composition of the soil, whereas treatment $\mathrm{T} 4$, including macro and micronutrients (N100P75K75 + B3Zn6Fe6 kg/ ha) with the highest amount of fertiliser, significantly increased soil mechanical particles $(1.0-0.25 \mathrm{~mm}, 0.1-0.05 \mathrm{~mm}, 0.05-0.01 \mathrm{~mm})$ as compared to control without fertiliser.

Table 4. The effect of mineral fertilisers on the mechanical composition of irrigated soil in the Kibray district.

\begin{tabular}{|c|c|c|c|c|c|c|c|c|}
\hline \multirow{2}{*}{ Treatments } & \multicolumn{7}{|c|}{ Fraction (\%) } & \multirow{2}{*}{$\begin{array}{l}\text { Physical } \\
\text { Mud (\%) }\end{array}$} \\
\hline & $1.0-0.25$ & $0.25-0.1$ & $0.1-0.05$ & $0.05-0.01$ & $0.01-0.005$ & $0.005-0.001$ & $<0.001$ & \\
\hline Control & 1.42 & 2.01 & 13.99 & 36.40 & 12.90 * & $19.98 *$ & 13.30 & 43.70 * \\
\hline $\mathrm{N}_{75} \mathrm{P}_{50} \mathrm{~K}_{50}$ & 2.02 & 3.36 & 16.10 * & 35.11 & 11.10 & 18.20 & 14.11 * & 43.41 \\
\hline $\mathrm{N}_{125} \mathrm{P}_{100} \mathrm{~K}_{100}$ & 2.47 & 3.54 * & 14.52 & $36.72 *$ & 11.22 & 17.68 & 13.85 & 42.75 \\
\hline $\begin{array}{l}\mathrm{N}_{100} \mathrm{P}_{75} \mathrm{~K}_{75} \\
+\mathrm{B} 3 \mathrm{Zn} 6 \mathrm{Fe} 6\end{array}$ & 3.78 * & 3.14 & 15.00 & 36.77 * & 9.70 & 17.51 & 14.10 * & 41.31 \\
\hline
\end{tabular}

* All the values are the average of three replicates $(n=3)$, and the mean with the same letter (superscript) in the columns are not significantly different $(p<0.05)$-(Tukey's test). 
Mineral fertilization with nitrogen, potassium, phosphorus, and micronutrients $(\mathrm{B}$, $\mathrm{Zn}$, and $\mathrm{Fe}$ ) positively affected active $\mathrm{P}, \mathrm{K}, \mathrm{N}$ content, total $\mathrm{P}$ and $\mathrm{K}$ content, and organic matter in the soil (Table 5). The highest values of total P, K and N content, organic matter, active phosphorus, and potassium were observed in soil with mineral fertiliser treatments. NPK (125:100:100 kg/ha) and NPK + BZnFe (100:75:75:3:6:6 kg/ha) improved essential nutrients in soil as compared to control and NPK (75:50:50 kg/ha) treatments. The NPK + BZnFe (100:75:75:3:6:6 kg/ha) treatment significantly increased active P content by $40 \%$, total $\mathrm{P}$ content by $38 \%$ and total $\mathrm{K}$ content by $22 \%$ in comparison to the control without mineral fertiliser. Several other authors also reported the nutrient contents in the soil before and after plant cultivation [39,40]. Some other studies about poultry manure showed limitations so that NPK alone or with a combination of other nutrient fertilisers could increase the essential macronutrients in soil [41]. Dinesh et al. [42] reported the chemical nutrient management in soil and found enhancement of total $\mathrm{N}$ content in soil containing rainfed ginger (Zingiber officinale Rosc.) tuber crops. Similarly, the N, P and K content in soil was also increased using NPK application (100: 60: $60 \mathrm{~kg} / \mathrm{h}$ ) [43].

Table 5. The effect of mineral fertilisers on agrochemical properties of irrigated soil in Kibray district.

\begin{tabular}{|c|c|c|c|c|c|c|c|c|c|}
\hline \multirow[t]{2}{*}{ Treatments } & \multicolumn{2}{|c|}{$\begin{array}{c}\text { Active Phosphorus } \\
\text { and Potassium, mg/kg }\end{array}$} & \multirow{2}{*}{$\begin{array}{c}\mathrm{N}-\mathrm{NO}_{3} \\
\mathrm{mg} / \mathrm{kg}\end{array}$} & \multicolumn{2}{|c|}{ Total (\%) } & \multirow[t]{2}{*}{ N (\%) } & \multirow{2}{*}{$\begin{array}{c}\text { Organic } \\
\text { Carbon (\%) }\end{array}$} & \multirow{2}{*}{$\begin{array}{c}\text { Organic } \\
\text { Matter (\%) }\end{array}$} & \multirow[t]{2}{*}{$\mathbf{C} / \mathbf{N}$} \\
\hline & $\mathrm{P}_{2} \mathrm{O}_{5}$ & $\mathrm{~K}_{2} \mathrm{O}$ & & $\mathrm{P}_{2} \mathrm{O}_{5}$ & $\mathrm{~K}_{2} \mathrm{O}$ & & & & \\
\hline Control & 34.85 & 238.88 & 12.01 & 0.21 & 0.80 & $0.098 *$ & 0.9270 & 1.60 & 9.3 \\
\hline $\mathrm{N}_{75} \mathrm{P}_{50} \mathrm{~K}_{50}$ & 40.02 & 245.88 & 12.57 & 0.25 & 0.84 & 0.098 * & 0.9628 & 1.65 & 9.7 \\
\hline $\mathrm{N}_{100} \mathrm{P}_{75} \mathrm{~K}_{75}$ & 44.60 & 249.47 & 25.58 & 0.27 & 0.95 & 0.097 & 0.9686 & 1.65 & 9.8 \\
\hline $\begin{array}{c}\mathrm{N}_{125} \mathrm{P}_{100} \mathrm{~K}_{100} \\
+\mathrm{B}_{3} \mathrm{Zn}_{6} \mathrm{Fe}_{6}\end{array}$ & $48.9 *$ & 251.44 * & 37.98 * & $0.29 *$ & 0.98 * & $0.098^{*}$ & $0.9944^{*}$ & 1.70 * & $10.1^{*}$ \\
\hline
\end{tabular}

* All the values are the average of three replicates $(n=3)$, and the mean with the same letter (superscript) in the columns are not significantly different $(p<0.05)$-(Tukey's test).

As a result of the experiments, there was a significant change in chlorine and sulphate ions. The amount of chlorine ion was found to be $0.20 \mathrm{mg} / \mathrm{eq}$ with control, while the NPK + BZnFe application (100:75:75:3:6:6 kg/ha) showed $0.13 \mathrm{mg} / \mathrm{eq}$ in the soil (Table 6). The NPK + BZnFe (100:75:75:3:6:6 kg/ha) treatment enhanced Ca and Mg content significantly compared to all other treatments. Overall, the results showed that the NPK + BZnFe (100:75:75:3:6:6 kg/ha) significantly improved soil properties.

Table 6. The effect of mineral fertilisers on chemical properties of irrigated soil in the Kibray district.

\begin{tabular}{|c|c|c|c|c|c|c|c|c|c|c|c|}
\hline \multirow[b]{2}{*}{ Treatments } & \multirow[b]{2}{*}{$\begin{array}{c}\mathrm{CO}_{2} \\
(\%)\end{array}$} & \multicolumn{2}{|c|}{ Alkalinity } & \multirow[b]{2}{*}{$\begin{array}{c}\mathrm{Cl} \\
(\%)\end{array}$} & \multirow[b]{2}{*}{$\begin{array}{c}\mathrm{Cl} \\
\mathrm{mg} / \mathrm{eq}\end{array}$} & \multirow[b]{2}{*}{$\begin{array}{c}\mathrm{SO}_{4} \\
(\%)\end{array}$} & \multirow[b]{2}{*}{$\begin{array}{c}\mathrm{SO}_{4} \\
\mathrm{mg} / \mathrm{eq}\end{array}$} & \multirow[b]{2}{*}{$\begin{array}{l}\mathrm{Ca} \\
(\%)\end{array}$} & \multirow[b]{2}{*}{$\begin{array}{c}\mathrm{Ca} \\
\mathrm{mg} / \mathrm{eq}\end{array}$} & \multirow[b]{2}{*}{$\begin{array}{l}\mathrm{Mg} \\
(\%)\end{array}$} & \multirow[b]{2}{*}{$\begin{array}{c}\mathrm{Mg} \\
\mathrm{mg} / \mathrm{eq}\end{array}$} \\
\hline & & $\begin{array}{c}\text { Total } \\
\mathrm{HCO}_{3} \\
(\%)\end{array}$ & $\begin{array}{c}\text { Total } \\
\mathrm{HCO}_{3} \\
\text { mg/eq }\end{array}$ & & & & & & & & \\
\hline Control & 8.20 & 0.02 & $0.36^{*}$ & $0.05 *$ & $0.20 *$ & $1.07^{*}$ & $0.50 *$ & 0.18 & 19.01 & 8.20 & 0.02 \\
\hline $\mathrm{N}_{75} \mathrm{P}_{50} \mathrm{~K}_{50}$ & 8.21 & 0.02 & 0.35 & $0.05 *$ & 0.16 & 1.06 & 0.45 & $0.21 *$ & $\begin{array}{c}22.01 \\
*\end{array}$ & 8.21 & 0.02 \\
\hline $\mathrm{N}_{125} \mathrm{P}_{100} \mathrm{~K}_{100}$ & 8.25 & 0.02 & 0.34 & 0.04 & 0.15 & 0.67 & 0.42 & 0.18 & 21.14 & 8.25 & 0.02 \\
\hline $\mathrm{N}_{100} \mathrm{P}_{75} \mathrm{~K}_{75}+\mathrm{B}_{3} \mathrm{Zn}_{6} \mathrm{Fe}_{6}$ & $8.32 *$ & $0.10 *$ & 0.32 & 0.03 & 0.13 & 0.54 & 0.31 & 0.17 & 20.41 & $8.32 *$ & 0.10 * \\
\hline
\end{tabular}

$*$ All the values are the average of three replicates $(n=3)$, and the mean with the same letter (superscript) in the columns are not significantly different $(p<0.05)$ - (Tukey's test).

\subsection{Impact of Mineral Fertilisers on Soil Enzyme Activity}

The data show that mineral fertilisers increased urease activity in the soil (Figure 1). The urease activity was significantly enhanced by the treatment of NPK $(125: 100: 100 \mathrm{~kg} / \mathrm{ha})$. The maximum urease activity was recorded using NPK + BZnFe (100:75:75:3:6:6 kg/h) compared to control and other treatments. NPK fertiliser and other microelements increased the $\mathrm{N}$, $\mathrm{P}$, and $\mathrm{K}$ concentrations in the soil. The amount of organic $\mathrm{Ca}, \mathrm{Mg}$, and $\mathrm{pH}$ in the soil 
was increased due to excellent decomposition and resulted in the highest release of organic matter and other nutrients inside the soil. The soil $\mathrm{pH}$ increased due to the presence of base cations which are released upon microbial decarboxylation [44].

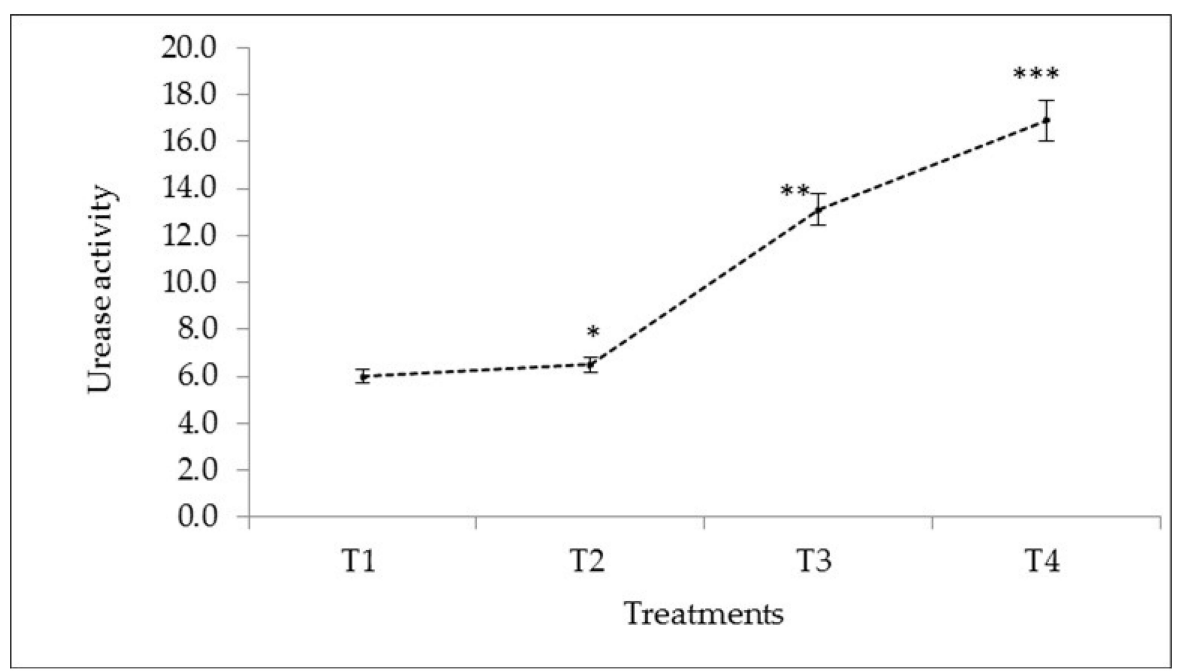

Figure 1. The effect of mineral fertilisers on urease activity of irrigated soil in Kibray district, Tashkent Region, Uzbekistan. ( $p$ values showing significantly different at $p<0.05^{*}, p<0.01^{* *}, p<0.001^{* * *}$ as compared to control (T1)). Bars represent \pm SD values.

In the present study, the data indicated that the increased fertiliser combinations of the NPK (125:100:100 kg/ha) and NPK + BZnFe applications (100:75:75:3:6:6 kg/ha) significantly enhanced invertase activity in the soil (Figure 2). The application of NPK (125:100:100 kg/ha) significantly increased invertase activity by $50 \%$ compared to control. In contrast, the combination of macro and micronutrients, NPK + BZnFe (100:75:75:3:6:6 kg/ha), significantly enhanced the invertase activity by $58 \%$ more than in control without fertiliser.

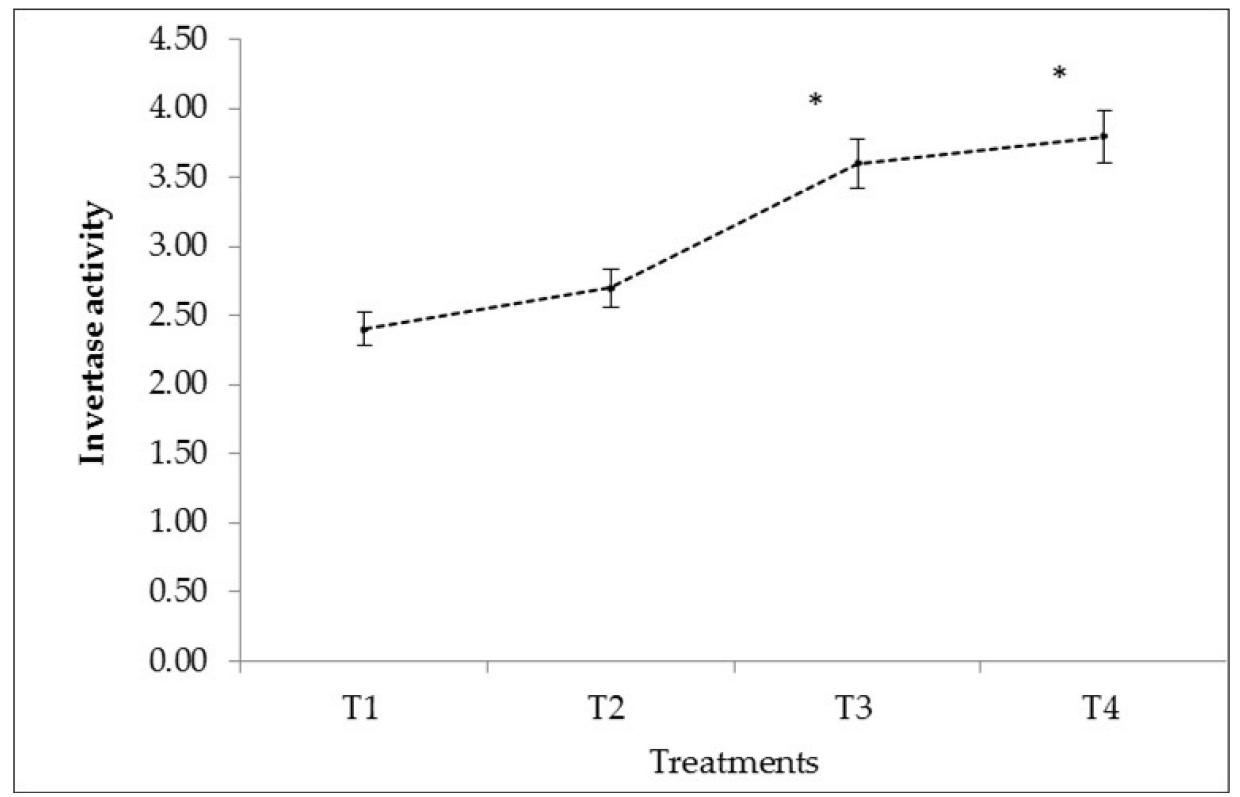

Figure 2. The effect of mineral fertilisers on invertase activity of irrigated soil in Kibray district, Tashkent Region, Uzbekistan. ( $p$ values showing significantly different at $p<0.05 *$ as compared to control (T1)). Bars represens \pm SD values. 
The data in Figure 3 show that mineral fertilisers increased the catalase activity of the soil. The increases in catalase activity reached a maximum with a higher amount of NPK (125:100:100 kg/ha) and NPK + BZnFe (100:75:75:3:6:6 kg/ha) treatments as compared to the control. However, NPK + BZnFe (100:75:75:3:6:6 kg/ha) showed a significant increase in catalase activity over the control and other treatments-T-2 and T-3.

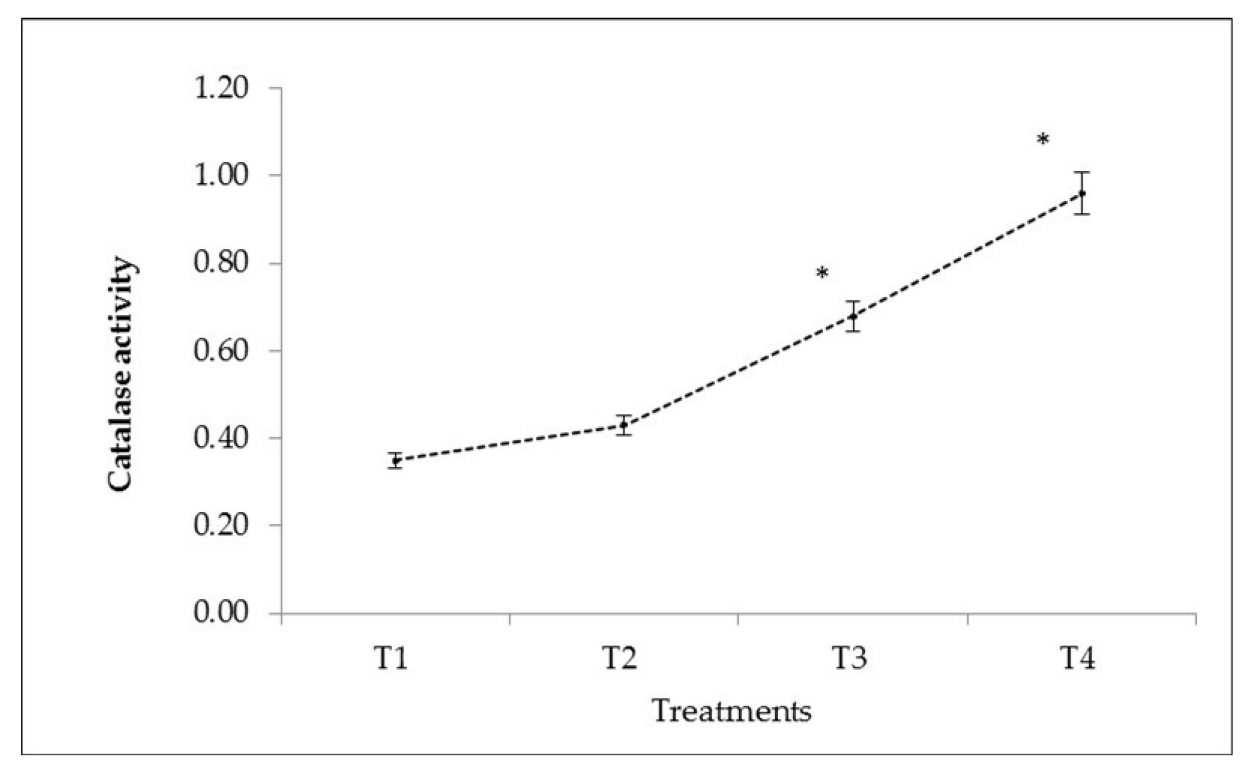

Figure 3. The effect of mineral fertilisers on catalase activity of irrigated soil in Kibray district, Tashkent Region, Uzbekistan. ( $p$ values showing significantly different at $p<0.05 *$ as compared to control (T1)). Bars represent \pm SD values.

Overall the results of the present study showed that the NPK + BZnFe application (100:75:75:3:6:6 kg/ha) significantly increased all three enzymes such as urease (Figure 1) invertase (Figure 2), and catalase activity (Figure 3) in soil. Similar findings were confirmed earlier by Srinivasan et al. [45] and reported that NPK (75: 50: $50 \mathrm{~kg} / \mathrm{h}$ ) increased the urease activity by $27 \%$ in the soil. In this context, Singh et al. [46] and Allison et al. [47] observed the enzymatic activities in soil, which was enhanced by applying different mineral fertilisers. The literature showed no studies so far that have reported on the determination of soil enzyme activity during turmeric cultivation in Uzbekistan.

For the first time in Uzbekistan, the content of mineral elements in cultivated turmeric rhizome was studied. This study clearly explained that the NPK + BZnFe (100:75:75:3:6:6 $\mathrm{kg} / \mathrm{ha}$ ) significantly increased the macro and micronutrient contents in turmeric rhizome. The combined application of the NPK + BZnFe (100:75:75:3:6:6 kg/ha) also significantly improved the essential nutrients and enzymatic activities in the soil. These results suggested that the NPK + BZnFe (100:75:75:3:6:6 kg/ha) can produce the most significant yield with high quality of turmeric rhizome improving soil properties in Uzbek soil-climate conditions.

\section{Materials and Methods}

\subsection{Experimental Design}

Turmeric (Curcuma longa) rhizome was used for this present study. A microplot experiment was conducted to study the effect of mineral fertilisers on mineral nutrients in turmeric rhizome and soil properties. The experiment was carried out in randomized block design with three replications at the Institute of Genetics and Plant Experimental Biology, Kibray, Tashkent Region, Uzbekistan. Experimental treatments included:

T1-Control

T2-N75P50K50kg/ha

T3-N125P100K100kg/ha 


\section{T4-N100P75K75+B3Zn6Fe6kg/ha}

Rhizomes were sown on 18 March 2019, and harvesting was performed on 18 November 2019.

\subsection{Measurement of Plant Nutrients}

Turmeric rhizomes were harvested after 240 days of cultivation. These harvested rhizome samples were prepared for analysis. Analysis was carried out in a special autoclave under the influence of hydrogen peroxide $\left(\mathrm{H}_{2} \mathrm{O}_{2}\right)$ and nitric acid $\left(\mathrm{HNO}_{3}\right)$ as disintegrating reagents for $6 \mathrm{~h}$ using a special microwave oven until the plant samples were converted into atomic elements. Sample volumes were accurately measured, and then $2.0 \% \mathrm{HNO}_{3}$ was added. The analysis was carried out on an optical emission spectrometer with inductively coupled argon plasma (2100DV; USA) [48].

\subsection{Analysis of Soil Nutrient}

Soil samples were collected randomly from a microplot of the experimental site in three replicates. To determine the soil properties before experimenting, soil samples were taken. The mechanical composition of the soil was determined by modified Kachinsky's method [49]. Mobile compounds of phosphorus and potassium were determined by the Michigan method modified by CINAO [50], while the total phosphorus and potassium contents were determined using another modified method [51]. The total nitrogen content was observed according to the method of Soils [52]. The salinity level of soil was also determined by the water extraction method [53]. Analysis of soil properties is shown in Table 7,Table 8,Table 9.

Table 7. The mechanical composition of irrigated soil in the Kibray district.

\begin{tabular}{|c|c|c|c|c|c|c|c|c|c|}
\hline \multirow{2}{*}{$\begin{array}{l}\text { Land Use } \\
\text { Types }\end{array}$} & \multicolumn{7}{|c|}{ Size of Mechanical Particle/mm } & \multirow{2}{*}{$\begin{array}{l}\text { Physical } \\
\text { Mud (\%) }\end{array}$} & \multirow{2}{*}{$\begin{array}{c}\text { The Mechanical } \\
\text { Content }\end{array}$} \\
\hline & $1-0.25$ & $0.25-0.1$ & $0.1-0.05$ & $0.05-0.01$ & $0.01-0.005$ & $0.005-0.001$ & $<0.001$ & & \\
\hline $\begin{array}{l}\text { Cultivated } \\
\text { land }\end{array}$ & 4.35 & 6.89 & 10.99 & 36.18 & 12.64 & 14.99 & 13.96 & 41.59 & Light sand \\
\hline
\end{tabular}

Table 8. The agrochemical properties of irrigated soil in the Kibray district.

\begin{tabular}{|c|c|c|c|c|c|c|c|c|c|}
\hline \multirow[t]{2}{*}{$\begin{array}{c}\text { Land Use } \\
\text { Types }\end{array}$} & \multicolumn{2}{|c|}{$\begin{array}{l}\text { Active Phosphorus and } \\
\text { Potassium, mg/kg }\end{array}$} & \multirow{2}{*}{$\begin{array}{c}\mathrm{N}-\mathrm{NO}_{3} \\
\mathrm{mg} / \mathrm{kg}\end{array}$} & \multicolumn{2}{|c|}{ Total (\%) } & \multirow[t]{2}{*}{ N (\%) } & \multirow{2}{*}{$\begin{array}{c}\text { Organic } \\
\text { Matter (\%) }\end{array}$} & \multirow[t]{2}{*}{ C (\%) } & \multirow[t]{2}{*}{$\mathrm{C} / \mathrm{N}$} \\
\hline & $\mathrm{P}_{2} \mathrm{O}_{5}$ & $\mathrm{~K}_{2} \mathrm{O}$ & & $\mathrm{P}_{2} \mathrm{O}_{5}$ & $\mathrm{~K}_{2} \mathrm{O}$ & & & & \\
\hline $\begin{array}{l}\text { Cultivated } \\
\text { land }\end{array}$ & 33.0 & 481.60 & 95.10 & 0.170 & 0.69 & 0.091 & 1.656 & 0.960 & 10.5 \\
\hline
\end{tabular}

Table 9. The chemical properties of irrigated soil in the Kibray district.

\begin{tabular}{|c|c|c|c|c|c|c|c|c|c|c|c|}
\hline \multirow[b]{2}{*}{$\begin{array}{l}\text { Land Use } \\
\text { Types }\end{array}$} & \multirow[b]{2}{*}{$\mathrm{CO}_{2} \%$} & \multicolumn{2}{|c|}{ Alkalinity } & \multicolumn{2}{|c|}{$\mathrm{Cl}$} & \multicolumn{2}{|c|}{$\mathrm{SO}_{4}$} & \multicolumn{2}{|c|}{$\mathrm{Ca}$} & \multicolumn{2}{|c|}{$\mathrm{Mg}$} \\
\hline & & $\begin{array}{c}\text { Total } \\
\mathrm{HCO}_{3}(\%)\end{array}$ & $\begin{array}{c}\text { Total } \\
\mathrm{HCO}_{3} \text {, } \\
\text { М.эКв }\end{array}$ & $(\%)$ & mg/eq & $(\%)$ & $\mathrm{mg} / \mathrm{eq}$ & $(\%)$ & mg/eq & $(\%)$ & mg/eq \\
\hline Cultivated & 5.41 & 0.023 & 0.08 & 0.056 & 0.20 & 0.080 & 0.50 & 0.230 & 11.48 & 0.07 & 5.73 \\
\hline
\end{tabular}

\subsection{Analysis of Soil Enzymes}

Urease activity of soil was assayed using the method by Xaziev [54]. Total $2.5 \mathrm{~g}$ of soil sample were mixed with $0.5 \mathrm{~mL}$ of toluene for $15 \mathrm{~min}$. Then, $2.5 \mathrm{~mL}$ of $10 \%$ urea and $5 \mathrm{~mL}$ citrate buffer were added and incubated at $38^{\circ} \mathrm{C}$ in an incubator for $24 \mathrm{~h}$. Then, this working mixture was diluted with double distilled water and filtered. Then, $4.0 \mathrm{~mL}$ of sodium phenate with $3.0 \mathrm{~mL}$ of sodium hypochlorite were added into $1.0 \mathrm{~mL}$ of filtrate and 
diluted with $50 \mathrm{~mL}$ and kept for $20 \mathrm{~min}$ at room temperature. Urease activity ( $\mathrm{mg} \mathrm{NH}_{4} / \mathrm{g}$ ) of soil was measured at wavelengths of $578 \mathrm{~nm}$ using a spectrophotometer. Invertase and catalase activity of soil were also assayed using the method described by Xaziev [54]. In the invertase activity, a total of $5.0 \mathrm{~g}$ of dried soil was used for the experiment. In this dried soil, $15.0 \mathrm{~mL}$ of sucrose solution $(8.0 \%)$ with $5.0 \mathrm{~mL}$ of double distilled water were added. Then, finally, in the end, five drops of toluene were added and keep this soil mixed solution for $24 \mathrm{~h}$ incubation at $37^{\circ} \mathrm{C}$.

Then, incubated soil solution was centrifuged at $4000 \mathrm{rpm}$ for $5 \mathrm{~min}$. Then, $1.0 \mathrm{~mL}$ aliquot collected from the vial after centrifugation and was transferred into a volumetric flask containing $3.0 \mathrm{~mL}$ of 3.5-dinitrosalicylic acid and kept on the hotplate for $5 \mathrm{~min}$. Finally, the solution was kept for cooling up to room temperature. Then, quantification of glucose content was performed using the colorimetric method at the wavelength of $508 \mathrm{~nm}$ on a spectrophotometer. Invertase activity was expressed as $\mu \mathrm{g}$ glucose $\cdot \mathrm{g}^{-1}$ soil $\cdot \mathrm{h}^{-1}$. For catalase activity of the soil, a total of $2.0 \mathrm{~g}$ of thoroughly air-dried soil was mixed with $5.0 \mathrm{~mL}$ of $\mathrm{H}_{2} \mathrm{O}_{2}$ and $40.0 \mathrm{~mL}$ of double-distilled water. The mixture of this soil with this solution was shaken for $20 \mathrm{~min}$ at $150 \mathrm{rpm}$. The remaining hydrogen peroxide $\left(\mathrm{H}_{2} \mathrm{O}_{2}\right)$ was stabilized using $5.0 \mathrm{~mL}$ of sulfuric acid $\left(1.5 \mathrm{M} \mathrm{H}_{2} \mathrm{SO}_{4}\right)$ followed by centrifuging at $4000 \mathrm{rpm}$ for $5 \mathrm{~min}$. Then, the supernatant was used for titration with $0.05 \mathrm{M} \mathrm{KMnO}$. Catalase activity $\left(\mathrm{mL} \mathrm{KMnO}_{4} \mathrm{~g}^{-1}\right.$ soil $\left.\mathrm{h}^{-1}\right)$ of soil was measured at a wavelength of $480 \mathrm{~nm}$ using a spectrophotometer.

\subsection{Statistical Analyses}

All the experiments were replicated three times, and the mean values were considered. The data were statistically analysed by one-way analysis of variance (ANOVA) and multiple comparisons of HSD employing Tukey's test with Stat View Software (SAS Institute, Cary, NC, USA, 1998). The magnitude of the $p$-value determined the significance of various treatments on plant macro, micro, ultra-micronutrients, and soil nutrients $(p<0.05,0.01$ and 0.001).

Author Contributions: Conceptualisation and methodology-D.J., K.S. and Z.J.; Data curation-D.J., K.S. and A.A.; Investigation-D.J. writing—original draft-D.J.; Writing-review and editing-D.J., R.C., R.K., S.E. and J.A. All authors have read and agreed to the published version of the manuscript.

Funding: This work was supported by the Ministry of Innovative Development of the Republic of Uzbekistan (project number A- $\Phi$ A-2019-33, 2019-2022) and AIMST University for the financial support.

Data Availability Statement: All data, tables, figures, and results in paper are our own and original.

Conflicts of Interest: The authors declare there are no competing interests.

\section{References}

1. Egamberdieva, D.; Jabborova, D. Plant Microbiome: The Source for Biologically Active Compounds. In Biodiversity and Biomedicine; Ozturk, M., Egamberdieva, D., Pesici, M., Eds.; Elsevier Inc.: Amsterdam, The Netherlands, 2020; pp. 1-9.

2. Jabborova, D.; Annapurna, K.; Fayzullaeva, M.; Sulaymonov, K.; Kadirova, D.; Jabbarov, Z.; Sayyed, R.Z. Isolation and Characterisation of Endophytic Bacteria from Ginger (Zingiber officinale Rosc.). Ann. Phytomed. 2020, 9, 116-121. [CrossRef]

3. Mollova, S.; Fidan, H.; Antonova, D.; Bozhilov, D.; Stanev, S.; Kostova, I.; Stoyanova, A. Chemical Composition and Antimicrobial and Antioxidant Activity of Helichrysum italicum (Roth) G. Don Subspecies Essential Oils. Turk. J. Agric. For. 2020, 44, 371-378. [CrossRef]

4. Subasi, I. Seed Fatty Acid Compositions and Chemotaxonomy of Wild Crambe (Brassicaceae) Taxa in Turkey. Turk. J. Agric. For. 2020, 44, 662-670. [CrossRef]

5. Jabborova, D.; Enakiev, Y.; Sulaymanov, K.; Kadirova, D.; Ali, A.; Annapurna, K. Plant Growth-Promoting Bacteria Bacillus subtilis Promote Growth and Physiological Parameters of Zingiber officinale Roscoe. Plant Sci. Today 2021, 8, 66-71. [CrossRef]

6. Peter, B. Influence of Climatic Conditions on Curcumin Content and Colour Values of Turmeric. Material Sci. Eng. Int. J. 2020, 4, 92-96.

7. Mohanty, I.; Singh, A.D.; Dinda, A.; Joshi, S.; Talwar, K.K.; Gupta, S.K. Protective Effects of Curcuma longa on Ischemiare Perfusion Induced Myocardial Injuries and Their Mechanisms. Life Sci. 2004, 75, 1701-1711. [CrossRef] [PubMed] 
8. Rivera-Espinoza, Y.; Muriel, P. Pharmacological Actions of Curcumin in Liver Diseases or Damage. Liver Int. 2009, 29, 1457-1466. [CrossRef] [PubMed]

9. Kuroda, M.; Mimaki, Y.; Nishiyama, T. Hypoglycemic Effects of Turmeric (Curcuma longa L.) Rhizomes on Genetically Diabetic KKAy Mice. Bio. Pharm. Bull. 2005, 28, 937-939. [CrossRef]

10. Shytle, R.D.; Bickford, P.C.; Rezai-zadeh, K.; Hou, L.; Zeng, J.; Tan, J.; Sanberg, P.R.; Sanberg, C.D.; Roschek, B., Jr.; Fink, R.C.; et al. Optimised Turmeric Extracts Have Potent Antiamyloidogenic Effects. Cur. Alzheimer Res. 2009, 6, 564-571. [CrossRef]

11. Cho, J.Y.; Choi, G.J.; Lee, S.W.; Lim, H.K.; Jang, K.S.; Lim, C.H.; Cho, K.Y.; Kim, J.C. In Vivo Antifungal Activity against Various Plant Pathogenic Fungi of Curcuminoids Isolated from the Rhizomes of Curcuma longa. Plant Path. J. 2006, 22, 94-96. [CrossRef]

12. Haddad, M.; Sauvain, M.; Deharo, E. Curcuma as a Parasiticidal Agent: A Review. Planta Med. 2010, 77, 672-678. [CrossRef]

13. Jayaprakasha, G.K.; Rao, L.J.M.; Sakariah, K.K. Antioxidant Activities of Curcumin, Demethoxycurcumin and Bisdemethoxycurcumin. Food Chem. 2006, 98, 720-724. [CrossRef]

14. Cousins, M.; Adelberg, J.; Chen, F.; Rieck, J. Antioxidant Capacity of Fresh and Dried Rhizomes from Four Clones of Turmeric (Curcuma longa L.) Grown In Vitro. Ind. Crop. Prod. 2007, 25, 129-135. [CrossRef]

15. Li, S.; Yuan, W.; Deng, G.; Wang, P.; Yang, P.; Aggarwal, B. Chemical Composition and Product Quality Control of Turmeric (Curcuma longa L.). Pharm. Crop. 2011, 2, 28-54. [CrossRef]

16. Maheshwari, R.K.; Singh, A.K.; Gaddipati, J.; Srimal, R.C. Multiple Biological Activities of Curcumin: A Short Review. Life Sci. 2006, 78, 2081-2087. [CrossRef] [PubMed]

17. Singh, S.; Khar, A. Biological Effect of Curcumin and Its Role in Cancer Chemoprevention and Therapy. Anti-Cancer Agents Med. Chem. 2006, 6, 259-270. [CrossRef] [PubMed]

18. Adekiya, A.O.; Alori, E.T.; Aboyeji, C.M.; Dunsin, O.; Adegbite, K.A.; Aremu, C.O.; Bamiro, O.; Ejue, W.S.; Okunlola, F.O.; Adesola, O.O. MgO Fertiliser Sole and Combined with Organic and Inorganic Fertilisers: Effect on Soil Chemical Properties, Turmeric Performance, and Quality in a Tropical Alfisol. Sci. World J. 2019, 10, 2-8.

19. Tomori, W.B.; Obijole, O.A.; Aiyesanmi, A.F. Evaluation of Nutrient Status of Cropped and Degraded Soils-Research Note. Niger. J. Soil Sci. 2006, 16, 178-180.

20. Sanghamithre, V.K.; Menon, M.V. Effect of S, Ca and Mg on Fresh Rhizome Yield of Turmeric (Curcuma longa L.). J. Trop. Agri. 2014, 52, 158-161.

21. Chandra, R.; Desai, A.R.; Govind, S. Effect of Foliar Spray of Magnesium and Planting Materials on Growth and Yield of Turmeric. J. Hill Res. 1997, 10, 1-4.

22. Ishimine, Y.; Hossain, M.A.; Motomura, K.; Akamine, H.; Hirayama, T. Effects of Planting Date on Emergence, Growth and Yield of Turmeric (Curcuma longa L.) in Okinawa Prefecture, Southern Japan. Jpn. J. Trop. Agric. 2004, 48, 10-16.

23. Akamine, H.; Goya, A.; Tomoyose, T.; Kanna, K.; Fukuti, S.; Kinjo, K. Studies on Characteristics and Cultivation of Turmeric. (1) Plant Characteristics of Turmeric and Effect of Fertiliser. Sci. Bull. Agric. Univ. Ryukyus 1994, 41, 335-341.

24. Hossain, M.A.; Ishimine, Y. Growth, Yield and Quality of Turmeric (Curcuma longa L.) Cultivated on Dark-Red Soil, Gray Soil and Red Soil in Okinawa, Japan. Plant Prod. Sci. 2005, 8, 482-486. [CrossRef]

25. Egamberdieva, D.; Jabborova, D.; Berg, G. Synergistic Interactions between Bradyrhizobium japonicum and the Endophyte Stenotrophomonas rhizophila and Their Effects on Growth and Nodulation of Soybean under Salt Stress. Plant Soil 2016, 405, 35-45. [CrossRef]

26. Egamberdieva, D.; Wirth, S.; Jabborova, D.; Räsänen, L.A.; Liao, H. Coordination between Brady-rhizobium and Pseudomonas Alleviates Salt Stress in Soybean through Altering Root System Architecture. J. Plant Interact. 2017, 12, 100-107. [CrossRef]

27. Egamberdieva, D.; Jabborova, D.; Wirth, S.; Pravej, A.; Alyemeni, M.N.; Parvaiz, A. Interaction of Magnesium with Nitrogen and Phosphorus Modulates Symbiotic Performance of Soybean with Bradyrhizobium japonicum and Its Root Architecture. Front. Microb. 2018, 9, 1-11.

28. Jabborova, D.; Enakiev, Y.I.; Kakhramon, D.; Begmatov, S. Effect of Coinoculation with Bradyrhizobium japonicum and Pseudomonas putida on Root Morph-Architecture Traits, Nodulation, and Growth of Soybean in Response to Phosphorus Supply under Hydroponic Conditions. Bulg. J. Agril. Sci. 2018, 24, 1004-1011.

29. Ihenacho, L.U.; Okorie, H.A.; Chriso, I.E.; PeterOnoh, C.A. Effect of Poultry Manure on the Growth and Yield of Turmeric (Curcuma longa L.) in Nigeria. J. Agri. Vet. Sci. 2015, 8, 34-38.

30. Ogbonna, P.E.; Nweze, N.J. Evaluation of Growth and Yield Responses of Cocoyam (Colocasia esculenta) Cultivars to Rates of NPK 15:15:15 Fertiliser. Afr. J. Agril. Res. 2012, 7, 6553-6561.

31. Ojikpong, T.O. Effect of Planting Dates and NPK (15:15:15) Fertiliser on the Growth an Yield of Turmeric (Curcuma longa Linn). Int. J. Agric. Environ. Sci. 2018, 5, 42-46.

32. Grzebisz, W. Crop Response to Magnesium Fertilisation as Affected by Nitrogen Supply. Plant Soil 2013, 368, 23-39. [CrossRef]

33. Olubunmi, B.; Ajayi, S.; Funmilayo, A.; Akinyemi, T. Food Value of Two Varieties of Ginger (Zingiber officinale) Commonly Consumed in Nigeria. ISRN Nutr. 2013, 10, 2-4.

34. Hassan, S.A.; Mijin, S.; Yusoff, U.K.; Ding, P.; Wahab, P.E. Nitrate, Ascorbic Acid, Mineral and Antioxidant Activities of Cosmos Caudatus in Response to Organic and Mineral-Based Fertiliser Rates. Molecules 2012, 17, 7843-7853. [CrossRef]

35. Kavitha, P.R. Nutrient Management for Yield and Quality Improvement in Kacholam (Kaempferi agalanga L.). Master's Thesis, Kerala Agricultural University, Thrissur, India, 2012; p. 97. 
36. Chhibba, I.M.; Nayyar, V.K.; Kanwar, J.S. Influence of Mode and Source of Applied Iron on Fenugreek (Trigonella corniculata L). in a Typic Ustochrept in Punjab, India. Int. J. Agric. Biol. 2007, 9, 254-256.

37. Roy, A.; Cahatterjee, R.; Hassan, A.; Maitra, S.K. Effect of Zn, Fe and B on Growth, Yield and Nutrient Content in Leaf of Ginger. Ind. Cocoa Arecanut Spices J. 1992, 15, 99-101.

38. Halder, N.K.; Shill, N.C.; Siddiky, M.A.; Sarkar, J.; Gomes, R. Response of Turmeric to Zinc and Boron Fertilisation. J. Biol. Sci. 2007, 7, 182-187. [CrossRef]

39. Jabborova, D.; Davranov, K.; Egamberdieva, D. Antibacterial, Antifungal, and Antiviral Properties of Medicinal Plants. In Medically Important Plant Biomes: Source of Secondary Metabolites; Egamberdieva, D., Tiezzi, A., Eds.; Springer Nature Singapore Pte Ltd.: Singapore, 2019; pp. 51-65.

40. Jabborova, D.; Wirth, S.; Kannepalli, A.; Narimanov, A.; Desouky, S.; Davranov, K.; Sayyed, R.Z.; Enshasy, H.; AbdMalek, R.; Syed, A.; et al. Co-Inoculation of Rhizobacteria and Biochar Application Improves Growth and Nutrients in Soybean and Enriches Soil Nutrients and Enzymes. Agronomy 2020, 10, 1142. [CrossRef]

41. Adekiya, A.O.; Agbede, T.M.; Ojeniyi, S.O. The Effect of Three Years of Tillage and Poultry Manure Application on Soil and Plant Nutrient Composition, Growth and Yield of Cocoyam. Experi. Agric. 2016, 52, 466-476. [CrossRef]

42. Dinesh, R.; Srinivasan, V.; Hamza, S.; Manjusha, A.; Kumar, P.S. Short-Term Effects of Nutrient Management Regimes on Biochemical and Microbial Properties in Soils under Rainfed Ginger (Zingiber officinale Rosc.). Geoderma 2012, 173, 192-198. [CrossRef]

43. Yanthan, L.; Singh, A.K.; Singh, V.B. Effect of INM on Yield, Quality, and Uptake of N, P, and K by Ginger. Agropedology 2010, 20, 74-79.

44. Adekiya, A.O.; Agbede, T.M.; Aboyeji, C.M.; Dunsin, O.; Simeon, V.T. Biochar and Poultry Manure Effects on Soil Properties and Radish (Raphanus sativus L.) yield. Biol. Agric. Hort. 2018, 35, 33-45. [CrossRef]

45. Srinivasan, V.; Thankamani, C.K.; Dinesh, R.; Kandiannan, K.; Hamza, S.; Leela, N.K.; John, T.; Zachariah, T.J. Variations in Soil Properties, Rhizome Yield and Quality as Influenced by Different Nutrient Management Schedules in Rainfed Ginger. Agric. Res. 2019, 8, 218-230. [CrossRef]

46. Singh, A.K.; Singh, M.; Verma, N. Extraction, Purification, Kinetic Characterisation and Immobilisation of Urease from Bacillus sphaericus MTCC 5100. Biocatal. Agril. Biotech. 2017, 12, 341-347. [CrossRef]

47. Allison, S.D.; Nielsen, C.; Hughes, R.F. Elevated Enzyme Activities in Soils under the Invasive Nitrogen-Fixing Tree Falcataria moluccana. Soil Bio. Biochem. 2006, 38, 1537-1544. [CrossRef]

48. Sarabekov, A.; Matchanov, A.; G'ofurov, M.B.; Xamidova, G.; Maulyanov, S.; Babaev, B.; Jabborova, D. Element Analysis of Helichrysum maracandicum Collected in Different Regions of Uzbekistan. Plant Cell Biotech. Mol. Biol. 2021, 22, 53-59.

49. Tursunov, L. Soil Physics. In Determination of the Mechanical Composition of Soils by the Kachinsky Method; National Unversity of Uzbekistan Press: Tashkent, Uzbekistan, 7 September 2010; pp. 1-358.

50. GOST of Commonwealth of Independent States. Determination of Mobile Compounds of Phosphorus and Potassium by Machigin Method Modified by CINAO; GOST 26205-91, M.; Publishing House of Standards: Minsk, Belarus, 2005; pp. 1-10.

51. GOST of Commonwealth of Independent States. Methods for Determining Total Phosphorus and Total Potassium; GOST 26261-84, M.; Publishing House of Standards: Minsk, Belarus, 2005; pp. 1-10.

52. GOST of Commonwealth of Independent States. Methods for Determination of Total Nitrogen; GOST 26107-84, M.; Publishing House of Standards: Minsk, Belarus, 2002; p. 9.

53. Pancu, M.; Gautheyrou, J. Handbook of Soil Analysis Mineralogical, Organic and Inorganic Methods; Spinger: Berlin/Heidelberg, Germany; New York, NY, USA, 2003; p. 993.

54. Xaziev, F.X. Methods of Soil Enzymology; Publishing Nauka: Moscow, Russia, 3 May 2005; pp. 1-252. 